\title{
Oscylacje w mroku. Między niesamowitym a wzniosłym
}

Paweł Drabarczyk vel Grabarczyk

TEKSTY DRUGIE 2019, NR 4, S. 199-216

DOI: 10.18318/td.2019.4.12 | ORCID: 0000-0002-7264-4943

Niesamowitość? To wieczorna, zawsze wielowymiarowa ciemność między skalnymi ścianami.

Thomas Bernhard Mróz

Q łynny esej Freuda o niesamowitym rozpoczyna się, jak zauważa Harold Bloom, od znamiennego przemilczenia dotyczącego pejzażu ówczesnej estetyki, zdaniem twórcy psychoanalizy zajmującej się „w ogóle raczej tym, co piękne, wspaniałe, pociągające [...], aniżeli tym, co temu przeciwne, co odpychające, przykre"1. Freud w swym geście wprowadzającym do refleksji psychoanalitycznej das Unheimliche, należące do domeny tego, co „przeraźliwe, wywołujące lęk i grozę" ${ }^{2}$, zarzuca namysłowi estetycznemu prześlepianie uczuć negatywnych. Można by odnieść wrażenie, że zachowuje się tu nieco po konkwistadorsku, definiując swoją kategorię kosztem zlekceważenia formacji istniejących już przecież na tak wyznaczonym
Paweł Drabarczyk

vel Grabarczyk historyk sztuki, adiunkt w Instytucie Historii Sztuki UKSW. Wykłada również na warszawskiej i wrocławskiej ASP. Interesuje się wzajemnym oddziaływaniem sztuki i kategorii, takich jak wzniosłość, niewyobrażalne, numinosum, sacrum, czy niesamowite. W Instytucie Sztuki Polskiej Akademii Nauk obronił doktorat na temat kategorii wzniosłości w polskiej sztuce współczesnej.

1 S. Freud Niesamowite, w: tegoż Pisma psychologiczne, przeł. R. Reszke, Wydawnictwo KR, Warszawa 1997, s. 235.

2 Tamże. 
terytorium, obejmujących to, co „wspaniałe, pociągające”, a zarazem wywołujące przykrość. Ową próbę odseparowania das Unheimliche od całej tradycji wzniosłości, bo to właśnie ona całkiem skutecznie „obsługiwała” emocje negatywne od czasu swej, dokonującej się u progu nowoczesności, spektakularnej kariery, Harold Bloom punktuje jako „osobliwie słabą", zabieg szyty zbyt grubymi nićmi, który musi wyostrzyć czujność uważnego czytelnika³. W tym samym artykule, Freud and the Sublime, Bloom uznał niesamowite za najważniejszy XX-wieczny wkład do estetyki wzniosłości ${ }^{4}$; amerykański krytyk traktuje sam esej wręcz jako element Freudowskiej „teorii wzniosłości”, o tyle szczególnej, że dotyczącej zagadnienia, które zdaniem Blooma samo stało się tu przedmiotem wyparcia, gdyż raczej operuje pod powierzchnią słów, niż jest opisywane otwarcie. A zatem milczenie o wzniosłości, leżące u podstaw refleksji o niesamowitym Freuda, tego - jak go nazywa Bloom - „prose-poet of the Sublime", byłoby z punktu widzenia psychoanalizy znaczące, symptomatyczne. Zdefiniowane psychoanalitycznie niesamowite wkracza na scenę na skutek wyparcia wzniosłego. Skażona pewną uzurpacją względem tradycji sublimicystycznej geneza niesamowitego sprawia, że co jakiś czas powraca pytanie o - nieoczywiste już od zarania - wzajemne relacje obu kategorii, które zdaniem badacza das Unheimliche w architekturze, Anthony'ego Vidlera, bywają niekiedy „niemożliwe do odróżnienia”" Mimo że związki obu pojęć były już niejednokrotnie przedmiotem dyskusji, warto w moim przekonaniu zastanowić się na kilku przykładach, jak ich spotkanie poszerza pole interpretacyjne sztuk wizualnych. W niniejszym tekście chciałbym przyjrzeć się owemu spotkaniu, dokonującemu się w specyficznych warunkach: w mroku, rozumianym także jako materia artystyczna.W tym celu należy cofnąć się do czasów, w których pod piórem swoich głównych teoretyków, m.in. Edmunda Burke’a i Immanuela Kanta, estetyka wzniosłości coraz mocniej dochodziła do głosu. Właśnie w czasach wykuwania się teorii - i praktyki - wzniosłości szukać możemy źródeł pewnych napięć, czytelnych także we współczesnych realizacjach, spośród których kilka arbitralnie wybranych przywołuję w drugiej części artykułu. Pozwoli to, żywię nadzieję, lepiej zrozumieć współczesne utajone życie wzniosłości w kostiumie niesamowitego, a także pomoże nieco

3 H. Bloom Freud and the sublime: A Catastrophe Theory of Creativity, w: Psychoanalytic Literary Criticism, Maul Ellmann, London-New York, 1994, s. 183.

4 Tamże, s. 182.

5 A. Vidler Nieswojskie domy, przeł. G. Świtek, „Konteksty. Polska Sztuka Ludowa” 2004 nr 3/4 (266/267), s. 22. 
odsłonić „niesamowite” oblicze wzniosłości. Założono, że istnieją pewne momenty krytyczne obu kategorii: relacje przestrzenne, niepoliczalność, stosunek wobec transcendencji, awizulność, które choć skłaniają niektórych do zadekretowania ich nierozróżnialności, mogą jednak dać pewien wgląd w ich wykazujące odrębności funkcjonowanie.

\section{Łudzące (nie)podobieństwo przestrzeni}

Dla autora The Architecture of the Uncanny dokonywane z perspektywy niesamowitego interpretacje rycin Giovanniego Battisty Piranesiego, obrazów często uznawanych za paradygmatyczne dla estetyki wzniosłości, będą tu swego rodzaju „misreadingiem”. Jak zauważa Vidler, dla romantyków, w tym Thomasa de Quinceya, objawia się w nich inna jakość, która „wykracza poza zwyczajne rozkoszowanie się Burke’a nieokreślonością ruin, wzniosłością i ogłasza w pełni rozwiniętą koncepcję przestrzennej niesamowitości"6. To właśnie sposób odczuwania przestrzeni może naprowadzić na istotny rozdźwięk między das Erhabene a das Unheimliche: to pierwsze opisywalne jest przez wysokość, głębię i bezkres, to drugie zaś - ciszę, samotność, zamknięcie i głuchotę; niesamowite jest zatem przestrzenią mentalną, „w której zatracają się czasowość i przestrzenność"8. Różnica ta w znamienny sposób wybrzmiewa w cytowanym w Nieswojskich domach fragmencie opowiadania Piranèse Charlesa Nodiera, w którym „wzniosły”, biblijny i apokaliptyczny malarz John Martin został skontrastowany z dusznym, klaustrofobicznym, jak widzi to Nodier, Piranesim: Martin miałby doświadczać „koszmaru przestrzeni i tłumu. Piranesi z pewnością doświadczał koszmaru samotności i zamknięcia, więzienia i trumny - koszmaru kogoś, komu brakuje powietrza, aby oddychać, tchu, aby krzyczeć, przestrzeni, aby móc się uwolnić"

Mamy tu więc wyraźny kontrast między wartościami ekstrawertycznymi a introwertycznymi. Błąd w interpretacji Piranesiego jako piewcy wzniosłości

6 Za: tamże, s. 29.

7 Polskie pojęcie wzniosłość i niemieckie das Erhabene stosuję wymiennie. Przywołanie określenia niemieckiego należy odczytywać jako ukłon w stronę jednej z tradycji myślowych, która oprócz angielskiej - najmocniej przyczyniła się do rozwoju koncepcji. Do określenia angielskiego - the sublime - odwołuję się w pojęciach takich jak „sublimicyzm”, na określenie estetyki wzniosłości.

8 A. Vidler Nieswojskie domy, s. 30.

9 Tamże. 
na rycinach zapełnionych wizerunkami ruin zasadzałby się na niewłaściwym uchwyceniu właściwości jego przestrzeni, a więc przyjęciu, że wektor skierowany jest na zewnątrz, ku światu, podczas gdy jego strzałka wskazuje mroki wnętrza doświadczającego. Jeśli Vidler traktuje jako "misreading" spojrzenie na Piranesiego z perspektywy niesamowitego, to tym samym zdaje się przyznawać chronologiczne pierwszeństwo tym interpretatorom, którzy widzą we włoskim artyście piewcę wzniosłości. „Przewekslowanie” Piranesiego opatrującego wszak jedną ze swoich rycin sentencją Juliena Davida Le Roya „Pour ne pas faire de cet art sublime un vil métier où l'on ne feroit que copier sans choix" - na niesamowite, które dochodzi tu do głosu na skutek pewnego "uniku interpretacyjnego", byłoby więc, idąc za zaproponowanym przez Agatę Bielik-Robson terminem, jego „silnym prze-czytaniem”"10.

Czy jednak opozycyjne postawienie sprawy, przeciwstawienie niesamowitego wzniosłemu przy jednoczesnych próbach wytyczenia między nimi stałych linii demarkacyjnych, jest uprawnione? Czy nie jest raczej tak, że obie kategorie nierzadko występują obok siebie, przenikają się i dopełniają, lepiej więc być może mówić o płynności granicy? Wydaje się, że nader często alternatywa rozłączna jest fałszywa, a pójście tropem de Quinceya i Nodiera i „przepisanie” Piranesiego, tego zdaniem Wiesława Juszczaka „wielkiego poety historii"11, ze wzniosłości na niesamowite zdaje się znów amputować jego dorobkowi istotny wymiar. Wkład w estetykę wzniosłości, o którym pisał Bloom, należałoby traktować nie jako porządek konkurencyjny, lecz raczej jako poszerzenie (owszem, w wielu aspektach wywrotowe) porządku sublimicystycznego - wzajemna zależność obu kategorii (pozostając przy uznaniu ich niestabilnej odrębności) zdaje się przypominać często migotanie czy oscylację. Wygląda na to, że „Nodierowski” Piranesi został sprowadzony do wspólnego, „niesamowitego” mianownika; tymczasem oglądając liczne ryciny prezentujące ruiny jako „ślady symbolicznej doskonałości zniszczonej przez czas i żywioły”"12, w których jednak „magnificentia zwycięża vanitas"13 , trzeba uznać, że „wzniosłościowi” interpretatorzy mieli w swych intuicjach sporo racji. Przecież, oddając głos Juszczakowi, „budowle rosną

A. Bielik-Robson Podmiot jako akt woli: Harold Bloom i teoria dziedziczenia agonicznego, „Teksty Drugie" $1999 \mathrm{nr} 1 / 2$, s. 89.

W. Juszczak Piranesi, w: Wędrówka do źródeł, słowo/obraz terytoria, Gdańsk 2009, s. 390.

A. Vidler Nieswojskie domy, s. 25.

W. Juszczak Piranesi, s. 391. 
tu w nieobliczalnej skali, postaci obdartych lazzaroni gubią się wśród tłumu kolosalnych ciosów, pośród przesłaniających niebo obalonych kolumn, ułamków belkowań i kapiteli, które pokrywa splątany gąszcz krzewów i wielkich drzew. Człowiek [...] Przeniknięty uczuciem grozy, wzniosłości, patosu, musi też odczuć wspaniałość minionych ludzkich dokonań"14.

Oczywiście jest też inny Piranesi, autor dwóch serii „naprawdę nie dających się zbudować"15 Więzień, jakże innych od np. benthamowskich wizji penitencjarnych, naznaczonych transparentnością ${ }^{16} \mathrm{i}$ utylitaryzmem, prześwietlonych rozumem. To o Carceri Aldous Huxley pisał: „Prócz prawdziwych, historycznych więzien - tych nazbyt uporządkowanych i tych, gdzie anarchia tworzy piekło chaosu fizycznego oraz moralnego - są też inne więzienia, równie straszne w swej wyimaginowanej, bezcielesnej istocie: więzienia metafizyczne, osadzone w umyśle, obmurowane koszmarem i niezrozumieniem, gdzie łańcuchem jest niepokój kajdanami zaś poczucie osobistej, wrodzonej wręcz winy"17. Oto najmocniejszy może, choć nieprzywoływany przez Vidlera opis, upatrujący w Więzieniach wsobnej przestrzeni mentalnej, w której topografię zastępuje klaustrofobiczny majak, a obraz nie jest już odzwierciedleniem świata zewnętrznego, ale projekcją rzeczywistości psychicznej. I choć wiemy, że „wizja antycznego Rzymu kreowana przez Piranesiego zbliża się czasem na krok do jego czysto fantastycznych kompozycji”"18, można uznać, że w rzeczy samej monumentalnego Piranesiego studiującego ruiny Wiecznego Miasta dzieli od autora Carceri przepaść, by pozostać przy „otchłannej” metaforyce. Czy zatem przejście przez włoskiego autora rycin z otwartych miejskich przestrzeni do wnętrz kazamatów można symbolicznie uznać za przekroczenie progu oddzielającego domenę wzniosłego od niesamowitego? Niezupełnie.

\section{Zamknięcie w bezkresie}

W Vidlerowskiej analizie z dość regularną kadencją podkreślany jest nieskończony, niepoliczalny charakter przestrzeni w Piranezjańskich rycinach,

\footnotetext{
14 Tamże.

15 Tamże.

16 Por. A. Vidler Mroczna przestrzeń, w: autoportret 4 [47], 2014, s. 6.

17 A. Huxley Więzienia, przeł. D. Kozińska, w: Panoptykon. Architektura i teatr więzienia, katalog wystawy, Zachęta, Warszawa 2005, s. 15.

18 W. Juszczak Piranesi, s. 390.
} 
konstruowanych według zasady niedomykającego się ciągu powtórzeń; fakt, który skłonił jedną z interpretatorek serii Carceri do stwierdzenia otwartymi słowy „nadmiarowości” tych wizji: „Wydawać by się mogło, że więzienie nieuchronnie kojarzyć się powinno z ciasnotą i ograniczeniem miejsca, w którym skazany ma przebywać. Piranesi odwraca ten akcent, ukazując więzienia, których główną cechą nie jest brak, ale nadmiar. Nadmiar, który na pierwszy rzut oka zdaje się zupełnie bezcelowy"19, szczególnie że sam Huxley podpowiada, iż „ten imponujący pomnik bezużyteczności ciągnie się w nieskończoność, równie bezkresny jak wszechświat" ${ }^{\text {20 }}$. Należałoby raczej mówić o współwystępowaniu obu skrajności, braku naznaczonego nadmiarem czy też nadmiaru napiętnowanego brakiem, multiplikacji ciasnoty i rozmycia granic. Ów przestrzenny paradoks nie umyka zresztą uwadze niektórych komentatorów. Pisze bowiem belgijski literaturoznawca George Poulet: „Więzienie Piranesiego to zarazem przestrzeń ograniczona i ograniczająca, przestrzeń zamykająca, a równocześnie tak rozległa i skomplikowana, że ten, co się w niej zabłąka, może nigdy nie osiągnąć jej granic. [...] Toteż wszystkie dzieła Piranesiego poświęcone zamknięciu w gigantycznym więzieniu wywołują zawsze u oglądającego ten sam zawrót głowy i uczucie duszności. Zagubić się - w lesie, w świecie, w głębokościach własnego istnienia - znaczy to samo, co być zamkniętym w bezkresie, mieć za strażnika nieskończoność" ${ }^{21}$. Styk niesamowitego ze wzniosłym nieraz będzie właśnie "zamknięciem w bezkresie".

Pomni na to, że zarówno brak, jak i bezmiar należą do klasycznego repertuaru figur zdefiniowanej przez Burke’a wzniosłości, możemy dostrzec, jak obie te jakości zostały tu „zainfekowane” przez niesamowite: prywacja otwartej przestrzeni implikuje poczucie duszności miejsca, bezmiar lochów zaś wiąże się z powtórzeniem, które także może być wehikułem das Unheimliche: przytaczając swoją przygodę we włoskim mieście, gdy gubiąc drogę kilka razy, trafiał w to samo miejsce, Freud zauważył, że doznanie niesamowitego może mieć związek z niezamierzonym powtarzaniem się określonej sytuacji²2.

19 M. Czapiga Piranesi. Nowożytny locus horridus, "Colloquia Anthropologica et Communicativa, Mit, prawda, imaginacja" 2011, s. 120.

A. Huxley Więzienia, s. 19.

G. Poulet Piranesi i romantyczni poeci francuscy, w: tegoż Metamorfozy czasu. Szkice krytyczne, wybór J. Błoński, M. Głowiński, przeł. W. Błońska, PIW, Warszawa 1977, s. 507-508. 


\section{Dwoiste oblicze grozy}

Istotnym miejscem wspólnym obu kategorii jest groza, niemniej grozy wzniosłej i grozy niesamowitego nie można w pełni utożsamiać; zresztą już Edmund Burke przekonywał, że nie wszystko, co budzi grozę, jest wzniosłe, próbował on przy tym wskazać pewien punkt krytyczny, za którym niebezpieczeństwo i przykrość są już po prostu tylko straszne ${ }^{23}$. Nie chodzi tu jednak tylko o kwestię eskalacji. Romantyczna niesamowitość kojarzy nam się nieodmiennie z grozą gotycką, predylekcją do horroru, zmysłem wyostrzonym na zjawiska „nadprzyrodzone", przedzieranie się do oswojonego świata tego, co racjonalny umysł wyrugował poza swoje granice.

Pisząc o związkach obu typów grozy, Anthony Vidler² zauważa, że „w hierarchii romantycznych gatunków niesamowitość była blisko powiązana choć zaskakująco odmienna - z bardziej majestatyczną i poważną «wzniosłością», podstawową kategorią tęsknoty, nostalgii i nieosiągalnego"25. Naprowadza on tym samym na istotny wątek, który pozwala uchwycić różnicę między „prymitywną gotycką grozą" żywiącą się niesamowitym a wzniosłością, postrzeganą, jak to gdzie indziej ujęła Agata Bielik-Robson, jako „wyrzutnia" w transcendencję $e^{26}$. To właśnie ta druga miałaby przejawiać się w paradygmatycznych dla sublimicyzmu ruinach na obrazach Caspara Davida Friedricha ${ }^{27}$, gdzie ujawniają się metafizyczne aspiracje wzniosłości - to nie nawiedzone cmentarze i ostańce zamków, w których straszy, jak anachronicznie podpowiadają nam nasze wyćwiczone w gotyckim repertuarze oczy, to raczej niegdyś wspaniałe dzieła ludzkich rąk, których wielkość przeminęła w konfrontacji z tym, co bezmierne i uczestniczące w jakiś sposób w boskiej nieskończoności.

Między ruinami u Friedricha a, przykładowo, walpolowskim zamczyskiem w Otranto, da się zapewne zbudować uzasadniony z punktu widzenia historii idei łącznik, niemniej tym pierwszym wciąż daleko do mnożących się na kartach gotyckich powieści gmachów nawiedzanych przez zjawy, upiory, złe

23 E. Burke Dociekania filozoficzne o pochodzeniu naszych idei wzniosłości i piękna, PWN, Warszawa 1968, s. 42-44.

24 A. Vidler The Architectural Uncanny: Essays in the Modern Unhomely, The MIT Press, Cambridge 1992.

A. Vidler Nieswojskie domy, s. 22.

A. Bielik-Robson W stronę estetyki antyideologicznej, w: tejże Cienie pod czerwona skała, słowo/ obraz terytoria, Gdańsk 2016, s. 144. 
moce, które kwestionują metafizycznie stabilną konstrukcję świata, z jej podziałem na porządek ziemski i pozaziemski; akcentując stany i byty przejściowe, płynne, destabilizujące. O ile bowiem klasyczna wzniosłość jest, idąc za etymologią, zbliżeniem się do nadproża, limesu, który powinniśmy traktować jako co do zasady jakość stałą, o tyle wywrotowe niesamowite dehermetyzuje granice i odpowiada za kontrabandę rozmaitych widm, jaka dokonuje się między zaświatami a „naszym” światem. Rozróżnienie to pozostaje w dużej części aktualne: we wzniosłości, mimo jej mocnych postmodernistycznych redakcji, wciąż bywają pokładane nadzieje na tak czy inaczej rozumianą transcendencję; w przypadku idei niesamowitego, której ambicje nie przekraczają granic naszego świata psychicznego, nikt raczej deklaracji w tym względzie nie wymaga ${ }^{28}$.

Owo pomieszanie porządków jest jedną z najistotniejszych różnic między tradycyjnie ujmowaną wzniosłością a niesamowitym, która determinuje różne modalności doświadczania granicy. „Wszystkie podgatunki - przekonuje Vidler - groteska, karykatura, baśń, melodramat, opowieść o duchach, horror - były tradycyjnie uznawane za formy wywrotowe wobec solidnych podstaw i transcendentnych ambicji wzniosłości"29. Nie przeszkadzało to jednak, szczególnie dwóm ostatnim podgatunkom, posługiwać się podobną scenografią, wizualnymi rekwizytami, odnosić do niemożliwości ukazania sił przemożnych i apelować do doświadczeń numinotycznych, które - jak wiemy z refleksji Rudolfa Otta - mogły mieć zabarwienie zarówno boskie, jak i infernalne.

\section{Paradoksy awizualności}

Jednym ze środków wyrazu wzniosłości, wyniesionym do szczególnej rangi przez Kantowską koncepcję przedstawienia negatywnego, jest awizualność, rozumiana przede wszystkim jako fiasko zmysłu wzroku, jednej z naszych władz zmysłowych, wobec porządku transcendentnego. Dlatego też sprzeczność między awizualną czernią przedstawienia negatywnego opisywanego przez królewieckiego filozofa a rozbuchaną wizualnością romantycznego

28 Subiektywizm niesamowitego jako osobliwego „przeczucia” podkreśla m.in. Nicholas Royle. "Niesamowite jest upiorne. Wiąże się z tym, co dziwne, dziwaczne, tajemnicze, a także z mglistym przeczuciem (ale nie przekonaniem) o istnieniu nadnaturalnego". N. Royle Niesamowite, przeł. M. Choptiany, w: autoportret $4[47], 2014$, s. 17. 
wzniosłego imaginarium, obfitującego w reprezentacje gór, wulkanów, mórz, nieboskłonów, jest w pewnym sensie pozorna; owe wizerunki wzniosłej natury w swej istocie stanowią jedynie blady cień tego, do czego oko faktycznie nie ma dostępu - jak pamiętamy, u Kanta fenomeny przyrody leżące u źródeł doświadczenia wzniosłości same nie są wzniosłe, mogą zaledwie kierować umysł w stronę idei należących do porządku wyższej celowości.

Dwukrotnie pojawiająca się w artykule Freuda zbitka słowna ,samotność, cisza i ciemność" prowokuje do namysłu nad przejściem od wiązanej z das Erhabene prywacji do funkcjonowania tego wątku w ramach das Unheimliche, a także nad specyficzną rolą (a)wizualności w tych dwóch kategoriach. U Burke'a groźna ciemność boskiego majestatu - autor Dociekań filozoficznych przytacza fragment z Raju utraconego Miltona, w którym jest ona dość paradoksalnym, działającym na zasadzie coincidentia oppositorum, skutkiem jasności promieniującej od boskiego tronu ${ }^{30}$ - spotyka się z ciemnością rozumianą jako wylęgarnia zabobonnych lęków (od których zresztą Burke w racjonalistycznym odruchu szybko się odcina): „Odczuje to każdy, kto rozważy, jak znacznie noc powiększa nasz lęk zawsze, ilekroć grozi nam niebezpieczeństwo i jak bardzo myśli o duchach i gnomach, o których nie jesteśmy w stanie utworzyć jasnych wyobrażeń, opanowują umysły [...]"31. Pobrzmiewa tu związek ciemności z tym, co niewyobrażalne, umykające zamknięciu w obrazie o zdefiniowanych konturach, choćby był to obraz mentalny. Rzuca się w oczy, że Burke, tak stawiając sprawę, oddala się od wzniosłości transcendentnej i zwraca się w stronę rzeczywistości psychicznej doświadczającego nocnej grozy. Duchy i gnomy wyrosłe na pożywce popularnych podań są równie nierealne, jak „upiorne krokodyle”, nawiedzające nocą mieszkanie pary bohaterów opowiadania, o którym wspomina Freud w swoim eseju s2 $^{32}$

Dość zaskakujące zresztą, że napotykamy u Burke'a, w rozdziale poświęconym brakowi jako jakości „sublimogennej”, niemal taką samą, różniącą się zaledwie kolejnością, sekwencję pojęć, jak u Freuda: to, co twórca psychoanalizy wiąże z niesamowitym, czyli „samotność, ciszę i ciemność, spotykamy

30 W kontekście związków światła i mroku warto wspomnieć o "uporczywej obecności jednego w drugim", na jaką zwracał uwagę Vidler. „To w intymnych relacjach tych dwóch elementów, w ich niesamowitej zdolności do przechodzenia jednego w drugie, kryje się wzniosłe jako narzędzie strachu - w dwuznaczności, która wprowadza śmierć do życia, mroczną przestrzeń w jasną". A. Vidler Mroczna przestrzeń, s. 8.

E. Burke Dociekania filozoficzne..., s. 65 . 
u irlandzkiego myśliciela: tu „pustka, ciemność, samotność i cisza” są tym, co budzi trwoge $e^{33}$. Ponieważ jakości te w każdym przypadku wiążą się z czym innym - $u$ pierwszego z nich wyobrażenie braku ma konotować wielkość, u twórcy psychoanalizy są to czynniki pozostające w związku z lękami dziecięcymi - trudno nie dostrzec tu zarówno szerokiego pola spotkania das Erhabene z das Unheimliche, jak i zarzewia istotnego rozdźwięku. Wzniosły mrok może być matrycą sensów, tajemniczą przestrzenią epifanii, w przypadku niesamowitego ciemność będzie lękowym ekranem projekcji, jednym z warunków umożliwiających zasiedlenie owej części mentalnej przestrzeni, tej, jak można być może rzec, „psychotopii”, przez twory wychodzące z naszej nieświadomości.

\section{Tworząc w ciemnościach, czyli artystyczna aktualność mroku}

Zasygnalizowane w tekście Vidlera różnice - przestrzenna, metafizyczna, wizualna - między niesamowitym a wzniosłością, objawiające się choćby w rozłożeniu akcentów, skłaniają do pytania, jak w polu sztuki wybrzmiewają obie kategorie. Choć na przykładzie zaledwie owych kilku przytoczonych powyżej interpretacji Piranesiego stwierdzić można, że nie brakuje zwolenników alternatywy rozłącznej (dzieło albo „niesamowite”, albo wzniosłe), wydaje się, że możliwe i równie uprawnione jest w niektórych przypadkach odczytanie tych samych obiektów z dwóch różnych, choć zazębiających się ze sobą perspektyw; co więcej, takie podejście pozwala na pochwycenie pewnej interpretacyjnej „wartości dodanej”, powstającej na styku obu kategorii. Znajduje to uzasadnienie tym bardziej, że funkcjonowanie obu kategorii w sztuce zasadza się na znaczeniotwórczej obecności widza-odbiorcy; to jego oko, aparat afektywny i psychiczny, nadaje sensy artystycznej realizacji i decyduje, której kategorii da pierwszeństwo. Czasem zresztą dwa równoważne, stykające się w pewnym punkcie tropy, poddaje sam artysta, świadomie rozgrywając w swojej pracy oscylację obu kategorii - także z powodu mocnego osadzenia współczesnych twórców w polu oddziaływania dyskursów teoretycznych warto w moim przekonaniu pochylić się nad dzisiejszymi realizacjami. Co zatem zostaje z wzniosłości po jej „mocnym prze-czytaniu” z perspektywy niesamowitego; czym jest niesamowite po odsłonięciu wzniosłościowej genezy jego „rekwizytorium”?

33 Owe opanowane umysły to te, które dają posłuch ludowym podaniom; E. Burke Dociekania..., s. 80-81. 
Twórców biorących ciemność za materię swoich prac dziś nie brakuje. By ukazać, jak fluktuują w tych samych pracach obie kategorie, przywołać można Mirosława Bałkę i Anetę Grzeszykowską - artystów bardzo różnych, których jednak, prócz predylekcji do mroku jako tworzywa, łączy to, że w polskim obiegu doczekali się, jako jedni z nielicznych, interpretacji pisanych $\mathrm{z}$ perspektywy niesamowitego ${ }^{34}$. Czy można uznać, że niesamowite $\mathrm{w}$ ich pracach pojawia się także jako swego rodzaju „misreading” estetyki wzniosłości, w którym możemy zrekonstruować obecność obu kategorii?

Przygotowując swoją pracę How It I ${ }^{35}$, monumentalny kontener ustawiony w 2009 roku w londyńskiej Hali Turbin, Mirosław Bałka wynotował listę skojarzeń, ujawniających jej wielorakie konteksty i znaczenia. Idąc tropem asocjacji podpowiadanych przez artystę, otrzymujemy swoisty melanż wątków prowadzących w obie interesujące nas strony: arka Noego, z całym jej kontekstem biblijnym i katastroficznym, sąsiaduje tu z zesłaną przez Jahwe plagą ciemności. Nie bez znaczenia jest to, że do wnętrza wypełnionego mrokiem kontenera prowadziło prostokątne wejście: Początek świata Courbeta, odsyłający do fantazji powrotu do łona matki i lęku przed pochowaniem żywcem - które zresztą są u Freuda dwoma wersjami tej samej fantazji spotkał się więc z Czarnym kwadratem Malewicza. I o ile Courbet dostarcza łatwego klucza otwierającego instalację Bałki na das Unheimliche (choć Žižek czyni z tego obrazu istotny element dyskursu wzniosłościowego, upatrując

34 Na potencjał niesamowitego w sztuce zwracał uwagę już Ernst Jentsch: „[...] prawdziwa sztuka może podejmować próby wywołania wrażenia niesamowitości, jednak zawsze czyni to wyłącznie za pomocą środków artystycznych i w zgodzie z artystyczną intencją". E. Jentsch O psychologii niesamowitego, przeł. A. Żukrowska, w: autoportret 4 [47], 2014, s. 33. Teoria niesamowitego posłużyła jako narzędzie pomocne przy interpretacji twórczości Mirosława Bałki m.in. Karolinie Iwańczyk, zob. tejże Nawiedzone galerie - o Niesamowitym, przestrzeni i sztuce, s. 17, praca dostępna online: http://publikacje.ils.uw.edu.pl/bitstream/handle/123456789/9436/K.\%2olwa\%C5\%84czyk\%2c\%20Nawiedzone\%2ogalerie.pdf?sequence=1\&isAllowed=y (dostęp 11.11.2017).

Listę tę analizuje nader szczegółowo P. Herkenhoff The Illuminating Darkness of "How it is", w: H. Sainsbury How It Is, Tate Publishing, London 2009, s. 50-105. Co interesujące, kategoria wzniosłości jako kontekst interpretacyjny pojawia się w tym artykule expressis verbis jedynie w kilku miejscach. Zdaniem Herkenhoffa Bałka nie zamierzał wywołać uczucia wzniosłości (s. 52), a jego poetyka jest wobec tej kategorii „odporna” (s. 72), jednocześnie autor eseju wskazuje, że intencją artysty było osiągnięcie nieprzedstawialnego (s. 52) - tak jakby nieprzedstawialne nie wpisywało się w estetykę wzniosłości, podobnie jak pojęcia i jakości, które Herkenhoff przywołuje w innych miejscach, m.in. bezgraniczność i niezmierzoność. W innym miejscu (s. 62) stwierdza, że How It Is stało się narzędziem parodiowania pojęcia wzniosłości i sublimacji, co należałoby uznać za pośrednie przyznanie, iż w ten sposób praca dialektycznie wpisuje się jednak na pewnym poziomie w estetykę wzniosłości. 
w nim kluczowego dla historii malarstwa gestu desublimacyjnego), o tyle czerń quadratum nigrum Malewicza, co udowodniły nader liczne interpretacje, może być zarówno postrzegana jako konotująca wysokość, bezkres i głębię (Burke'owskie jakości przytaczane przez Vidlera w jego analizie przestrzeni wzniosłego i niesamowitego), jak i płaskość, zamknięcie, uczucia klaustrofobiczne, charakterystyczne dla doświadczania niesamowitego, wpisując się tym samym w oba przestrzenne rejestry, ponieważ może być zarówno ekranem epifanii porządku transcendentnego, jak i projekcji rzeczywistości wewnętrznej.W rzeczy samej, co można wywieść właśnie z sugestii podsuwanych przez twórcę, wieloznaczność wynikająca z oscylacji mnożących się w ciemnym polu znaczeń „wzniosłych" i „niesamowitych” jest właśnie elementem strategii artysty, który podkreśla, że „nie boi się pustki”.

Nie jest to jedyny przypadek, gdy Bałka czerpie z obu: das Unheimliche i das Erhabene. To połączenie obu kategorii można było bardzo wyraźnie dostrzec w jego scenografii do spektaklu na motywach Czarodziejskiej góry Tomasza Manna (Czarodziejska góra, 2015), gdzie dochodzi między nimi do spektakularnej, zdawałoby się rozmyślnie zaplanowanej, wolty. Jak zaznaczał sam artysta, jego wizualna konfrontacja z Mannem oznaczała przejście od „Friedrichowskiego" krajobrazu, szczytów oglądanych oczyma Hansa Castorpa, do trzewi góry, która staje się czymś na kształt przekroju poprzecznego przez piramidę z korytarzami prowadzącymi do komór grobowych czy, idąc innym tropem, ciemnym kopcem kreta. „Intensywność «Czarodziejskiej góry» zdała mi się właśnie kretowiskiem, miejscem $w$ którym się jest, a nie na którym się staje. Tu nie chodzi o kontemplowanie widoków, ale kopanie, rycie, poszukiwanie w ciemnościach, wnętrzach, w bezdennej studni"36. W czasie spektaklu scenografia przewraca się, ,wybebesza”. Ten wywrócony na nice krajobraz przeistacza się w coś na kształt pejzażu mentalnego, przestrzeni nieświadomości zamieszkiwanej przez upiory, które już niedługo, w postaci szaleństwa wojen światowych i totalitaryzmów, miały wypełznąć na powierzchnię. Jest też miejscem, w którym (komory grobowe!) historia może pogrzebać nas żywcem. W pewnym sensie u Bałki niesamowite jest więc „lewą stroną” wzniosłego, mroczną przestrzenią, gdzie możemy szukać odpowiedzi, których nie jest w stanie dostrzec spojrzenie „samotnego młodzieńca stojącego na szczycie przed górskim krajobrazem". Interpretując dalej splatające się w nieoczywistym związku te dwie kategorie, można skonstatować, że niesamowite

36 Kretowisko Zauberberg, z Mirosławem Bałką rozmawia Paweł Drabarczyk, "Art \& Business” $2015 \mathrm{nr}$ 6, s. 60-63. 
przychodzi jako powracające wyparte; nader czytelna jest metafora wyparcia - wepchnięcia pod ziemię, do ciemnych jam, nor i korytarzy wszystkiego tego, co wadzić by mogło we wzniosłej samokontemplacji cywilizacji europejskiej, tego co zarazem było (i zapewne jest nadal) jej mrocznym rewersem. Ufundowanie wzniosłości kosztem niesamowitego nie jest zresztą konceptem nowym. Dla Schellinga, co zauważa Vidler, „Homerycka wzniosłość powstała w wyniku wyparcia niesamowitości" ciemnych mocy dawnych helleńskich kultów, zepchnięcia mrocznych aspektów greckiej religii do reglamentowanej domeny misteriów ${ }^{37}$. Scenograficzny koncept Bałki prowadzi nas innym śladem: aby Friedrichowski wędrowiec mógł się napawać wzniosłym widokiem z podniebnych szczytów, pod ziemię musiały zostać wepchnięte liczne mary: góra, z której esteta spogląda na świat, jest w istocie podminowana, stabilność obserwującego podmiotu wielce wątpliwa i wystarczy niezbyt wielki wstrząs (może ledwie huk z pistoletu Gawrilo Principa), by góra runęła i wypełzły z niej nasze upiory.

Artystką najczęściej chyba na polskiej scenie odczytywaną z perspektywy niesamowitego, przede wszystkim dzięki esejowi Krzysztofa Pijarskiego ${ }^{\mathbf{3 8}}$, jest Aneta Grzeszykowska. Trudno się temu dziwić - nie sposób oprzeć się wrażeniu, że świadomie czyni ona z das Unheimliche, czy wręcz wątków z Freudowskiego eseju, substancję swoich prac; weźmy np. Black (2009), w którym fluktuacje ciemności zaplatają się z motywami jakby żywcem zaczerpniętymi $\mathrm{z}$ niesamowitego. To, co może budzić zdziwienie, to przeoczenie przez krytykę sublimicystycznego bieguna tych prac. A nietrudno dostrzec, że przez kluczowe tu, jak zauważył Pijarski, ,klasyczne surrealistyczne motywy”, prześwieca estetyka wzniosłego.W jaki sposób?

Trop surrealistycznej niesamowitości jest oczywiście uzasadniony, otwierające ten film sekwencje, w których kończyny nagiego ciała artystki jedna po drugiej nikną w czerni, przywołują refleksje Freuda o niesamowitym pofragmentowanego ciała: „Odcięte członki, odrąbana głowa, dłoń oddzielona od ręki niczym w bajce Hauffa, stopy, które same tańczą [...], mają w sobie coś niezwykle niesamowitego, zwłaszcza jeśli [...] przypisuje się im cechę samodzielnej aktywności" ${ }^{39}$. Ciemność, która w pierwszej sekwencji pochłonęła

37 A. Vidler Nieswojskie domy, s. 25.

38 K. Pijarski Miłość i dziewczyna, w: A. Grzeszykowska Love Book, Raster, Warszawa 2012.

39 S. Freud Niesamowite, s. 255. Owa samodzielna aktywność odseparowanych od reszty ciała kończyn jeszcze mocniej dochodzi do głosu w innych "czarnych" filmach Grzeszykowskiej, Bolimorfii (2008), a przede wszystkim w Bólu głowy (2008). 
ciało, staje się otwartą przestrzenią onirycznego lotu na linie, w której przedmioty codzienne nabierają, niczym w dziecięcej fantazji, magicznych właściwości, wręcz ożywają, jak sznur stający się wężem - a jak pamiętamy, uczuciu niesamowitego szczególnie sprzyja niepewność co do tego, czy dany obiekt jest ożywiony, czy nie $\mathrm{e}^{40}$.Zresztą, jakby na potwierdzenie tropu nawiązującego do Piaskuna E.T.A Hoffmanna, któremu Freud poświęca wiele miejsca w swoim tekście, sznur-wąż staje się medium lęku przed oślepieniem - ruchem kobry przypuszcza atak na oczy bohaterki, faktycznie odejmując jej możliwość widzenia. Moment oślepienia zmienia relacje przestrzenne, teraz ciemność staje się twarda i nieprzyjazna, napiera na bohaterkę, wypycha ją poza kadr. Kolejna sekwencja obrazuje przeciskanie się bohaterki przez szczelinę w ciemności, zakończoną sceną kojarzącą się z narodzinami, choć tu byłyby to raczej narodziny à rebours, fantazja o powrocie do matczynego łona, „wejście do dawnej ojczyzny [die Heimat] synów ludzkich, miejsca, gdzie każdy był na samym początku i gdzie tylko jeden raz przebywał"41.

Jak jednak zwracał uwagę już Freud, fantazja ta jest wariantem innej, zdecydowanie lękowej: wizji pogrzebania żywcem, przebudzenia się we własnym grobie. Za chwilę ciemność staje się więc klaustrofobiczna; bohaterka, ściśnięta jak nagle powiększona Alicja po zjedzeniu magicznego ciastka, miota się między połaciami czerni napierającymi na nią jak ściany. Jej ruchy stają się coraz bardziej paniczne, łapczywie chwyta powietrze, ciemność staje się duszna. Fazę lękową tego snu przerywa krzyk. Na kilka sekund zapada absolutna ciemność. I tu następuje przeskok od znamionowanej przez Vidlerowskie „zamknięcie i duchotę” czerni do wzniosłej przestrzeni bezkresu: oto bohaterka rozpoczyna swój taniec, choć może lepiej byłoby powiedzieć: pływanie synchroniczne, na tle czerni nocnego nieba inkrustowanej światełkami. Synchroniczne, gdyż teraz bohaterki są dwie, jakby sklonowane (znów ukłon w stronę motywu Freudowskiego - tym razem sobowtóra). Sięgnięcie po przestrzeń wzniosłą daje szanse na afektywne kontrasty, prowadzące od uczucia lęku i przytłoczenia, po nieledwie gwiezdne ulgę i uwznioślenie właśnie.

Taka niebiańsko-kosmiczna wzniosłość jest także punktem odniesienia dla Piranesiańsko ambiwalentnej przestrzeni Bolimorfii. To znów czarny kosmos mentalny, przestrzeń zarazem smoliście gęsta, oblepiająca, ciasna czy wręcz dwuwymiarowa, a jednocześnie nieskończona i rozciągliwa,

\footnotetext{
40 Tamże, s. 246.

41 Tamże, s. 256.
} 
rozszerzająca się w miarę zaludniania jej przez kolejne byty - multiplikujące się najpierw kończyny „Anety”, później „Anety” same, uprawiające swój „balet mechaniczny" (Pijarski) przy wtórze nałożonych na siebie Ravelowskiego Bolera i Polimorfii Pendereckiego. W owym pomnożeniu synchronizujących swe ruchy „Anet” dostrzec możemy zarówno znany nam już choćby z Carceri sugerowany „sublimogenny” bezlik, jak i spotęgowany motyw sobowtóra, tu ściśle ze sobą splecione i przenikające się: ich mnogość pozwala na tworzenie z ciał geometrycznych, ornamentalnych konstelacji, formujących w końcu humanoidalne monstrum. Powstaje ono z ciał „Anet” niczym Lewiatan z poddanych na słynnym frontyspisie traktatu Hobbesa; to jemu przez chwilę podporzą dkowane są wszystkie ruchy, to ono kosztem indywidualności poszczególnych "ciał składowych" zyskuje monstrualną podmiotowość ciała kolektywnego. Nasuwa się tu skojarzenie z obrzędowością państw totalitarnych, gdy masy prezentują na stadionach układy choreograficzne w spektaklach operujących wzniosłością idei przekraczającej niepomiernie jednostkę. Pamiętamy, że we wzniosłość wpisany jest pewien zespół cech, który sprawia, że jest ona szczególnie podatna na niebezpieczne zawłaszczenia - Ryszard Nycz wspomina o języku totalitarnym jako o jednym z dyskursów „pasożytujących" na wzniosłości ${ }^{42}$.

\section{W poszerzonym ciemnym polu}

Ciemność How It Is i ciemność w filmach Grzeszykowskiej działa, rzecz jasna, na innych poziomach diegetycznych. Przywołując uwagi Gabrieli Świtek, zdaniem której „Bezpośredniość i eliminacja dystansu to cechy odróżniające doświadczenie przestrzenne od doświadczenia wzrokowego dzieł sztuki"43 , przyjąć trzeba, że to pierwsze wyznacza spotkanie z pracą Bałki; w Black, Bolimorfii czy Bólu głowy będziemy mieć do czynienia z tym drugim. Architektoniczny wymiar How It Is sprawiał, że odbiorca miał szanse „na własnej skórze” doświadczyć „pochłonięcia” przez przestrzeń, inaczej niż u Grzeszykowskiej, gdzie obcujemy z ciemnością zapośredniczoną przez medium. Nie przekreśla to jednak ich znaczenia dla namysłu nad skutkami zderzenia interesujących nas idei; w tym miejscu istotniejsze będzie wskazanie różnicy między (a)wizualnością wzniosłą

42 R. Nycz Rehabilitowanie wzniosłości, "Teksty Drugie” 1996 nr 2/3, s. 3.

43 G. Świtek Gry sztuki z architekturą: Nowoczesne powinowactwa i współczesne integracje, Wydawnictwo Naukowe UMK, Toruń 2013, s. 77. 
i „niesamowitą”. Ta pierwsza będzie raczej ciemnością oka patrzącego, ograniczonego w swoich możliwościach dostrzeżenia tego, co przekracza porządek zmysłowy; można by rzec, że wzniosłość przechodzi nad okiem do porządku wyższego. Awizualność wzniosłości wiąże się więc z przekonaniem, że istnieje jakieś niewyobrażalne, które jest także niepostrzegalne wzrokowo. Sublimacja (tu rozumiana nie psychoanalitycznie) będzie więc raczej prowadzić do absolutyzacji ciemności, czerni, awizualnego - mrok oczyszcza pole dla wyższych sensów, tworzy przestrzeń, w której nie będzie miejsca na zjawianie się przerażających Freudowskich krokodyli. Byłby to ruch wstecz, najważniejsze bowiem jest to, "co niewidoczne dla oczu”, to poza nimi dokonuje się ewentualna epifania.

Awizualność niesamowitego będzie ciemnością oka trwale lub przejściowo oślepionego. Gdy zewnętrzne bodźce zmysłowe ustają, nasze spojrzenie niejako kieruje się do wewnątrz, a ciemność jako ekran staje się podatna na „zakłócenia” przez projekcje umysłu. „Awizualny” znaczyłby tu tyle, co niewidziany fizycznym okiem; jednak nie tylko nie neguje to możliwości obrazu jako takiego, lecz także szeroko otwiera drzwi dla obrazów mentalnych. Będą to co do zasady wizje naznaczone lękowo, co sprawia, że możliwość pozytywnej rewaloryzacji ciemności, czerni, mroku staje się w sferze niesamowitego znacznie bardziej problematyczna niż w przypadku wzniosłego. Wzniosła czerń może być redemptywna, „niesamowita” co najwyżej fascynująca.

Zarysowującą się w powyższych kilku realizacjach artystycznych oscylację wzniosłe/niesamowite wiązać można z efemeryczną naturą samego das Unheimliche, które zjawia się niespodziewanie. Jak pisze Vidler, u Freuda „niewielki krok dzieli swojski dom od domu nawiedzonego"44 - wygląda na to, że dynamika ta rezonuje także w relacji wzniosłego i niesamowitego. Mimo swej chimeryczności, a może właśnie ze względu na nią, spotkanie owo nie może przebiegać bez konsekwencji. To właśnie mrok, ciemność są domeną, w której podstawowe założenia idei wzniosłości zostają podane w wątpliwość za sprawą wtargnięcia niesamowitego; dokonująca się bezpośrednio w „mrocznej przestrzeni" lub symbolicznie w jej reprezentacjach dehermetyzacja granic uderza w jeden z filarów das Erhabene. „Mroczna przestrzeń obejmuje mnie ze wszystkich stron i penetruje mnie o wiele głębiej niż jasna przestrzeń; dystynkcja między wnętrzem i zewnętrzem, a w konsekwencji także same narządy zmysłów w takim zakresie, w jakim są przystosowane do percepcji

A. Vidler, Nieswojskie domy, s. 27. 
zewnętrznej, odgrywają tutaj jedynie śladową rolę"45. W istocie jednym ze skutków interakcji wzniosłego i niesamowitego może być podważenie dystansu estetycznego, na którym ufundowane były klasyczne modele wzniosłości - to właśnie bezpieczny dystans, najczęściej rozumiany przestrzennie, był gwarantem tego, że wzniosła groza nie zamieniała się w paraliżujący lęk. Okazuje się, że przy doświadczeniu mroku, gdy „ego jest przepuszczalne dla ciemności, choć nie jest takie dla światła" ${ }^{\text {"6 }}$, dystans zostaje zrelatywizowany, a wzniosłość wychodzi z tego spotkania podminowana niesamowitym. Co więcej, rzecz dotyczy tu czegoś znacznie ważniejszego niż dystans rozumiany jako fizyczna odległość, faktycznie dochodzi tu do zakwestionowania opozycji: ja doświadczające/świat zewnętrzny.

Poszerzenie pola za pomoca, jak widział to Bloom, „najważniejszego wkładu w estetykę wzniosłości" wpisuje w tę kategorię elementy, które jednocześnie mają wobec niej potencjał krytyczny, rozsadzają ją od środka. Jak uświadamiają nam "mroczne” realizacje artystyczne, niesamowite okazuje się niejednokrotnie czymś na kształt drugiego bieguna wzniosłego, jego dopełnienie o innym „ładunku elektrostatycznym”. Jeśli zgodzimy się, że czerń, mrok, ciemność są w logice wzniosłości jakościami szczególnie uprzywilejowanymi ze względu na wysuwane w ramach tej kategorii roszczenia transcendentne, niesamowite uzmysławia, jak kruchy, niestabilny jest mechanizm tej „wyrzutni”, w której nadzieje te są jakże podatne na ześlizgnięcie się do złudnego wnętrza umysłu. Niepokojąco podobne, a zarazem inne, niesamowite zjawia się niekiedy niemal jako sobowtór das Erhabene. Choć w niejednej kulturze spotkanie z sobowtórem uważane jest za zapowiedź śmierci, wygląda na to, że dla estetyki wzniosłości kryzys związany z pojawieniem się psychoanalitycznie zdefiniowanego niesamowitego okazał się ożywczy, a sztuka nie omieszkała tego wyzyskaćc ${ }^{47}$.

45 Słowa Eugène'a Minkowskiego z Le temps vécu, w: tegoż Le temps vécu. Etudes phénoménologiques et psychopathologiques, Collection de l'évolution psychiatrique, Paris 1933, s. 382-398, cytowane przez Rogera Caillois Mimicry and Legendary Psychasthenia, przeł. J. Shepley, w: October. The First Decade, 1976-1986, ed. by A. Michelson, R. Krauss, D. Crimp, J. Copjec, MIT Press, Cambridge 1987, s. 72. Za: A. Vidler Mroczna przestrzeń, s. 9.

46 Tamże.

47 Pragnę podziękować dr hab. Gabrieli Świtek za uwagi merytoryczne do niniejszego tekstu. Za wszelkie wsparcie winien jestem także podziękowanie dr Beacie Łazarz. 


\section{Abstract}

\section{Paweł Drabarczyk vel Grabarczyk}

CARDINAL STEFAN WYSZYŃSKI UNIVERSITY (WARSAW)

Oscillations in the Dark: Between the Uncanny and the Sublime

This article explores the relationship between the sublime and the uncanny in selected contemporary art works that thematise darkness. Building on Anthony Vidler's article "Unhomely Houses," Drabarczyk vel Grabarczyk juxtaposes Freud's essay The Uncanny with theoretical approaches to the sublime, especially Kant's and Burke's, also in the context of contemporary art. The contribution of the uncanny to the aesthetics of the sublime ought to be treated not as a competitive order but rather as a broadening of the code of the sublime. The mutual dependency of the uncanny and the sublime often appears as a shimmering or oscillation.

\section{Keywords}

sublime, uncanny, avisuality 